\title{
$\mathbf{S} \mathbf{F}$
}

$27^{\prime}$

I64 U. S. DEPARTMENT OF AGRICULTURE, BUREAU OF ANIMAL INDUSTRY.-BULLETIN 123.

A. D. MELVIN, Chief of Bureau.

Issued May $31,1910$.

\section{THE INFLUENCE OF LACTIC ACID ON THE QUALITY OF CHEESE OF THE CHEDDAR TYPE.}

\author{
BY \\ C. F. DOANE, \\ Assistant Dairyman, Dairy Division.
}

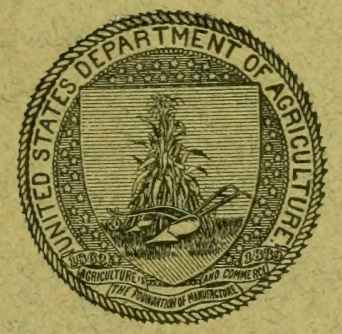

WASHINGTON :

GOVERNMENT PRINTING OFFICE.

1910. 
ช。 


U. S. DEPARTMENT OF AGRICULTURE, BUREAU OF ANIMAL INDUSTRY.-BULLETIN 123.

A. D. Melvin, Chief of Bureau.

\title{
THE INFLUENCE OF LACTIC ACID ON THE QUALITY OF CHEESE OF THE CHEDDAR TYPE.
}

\author{
BY \\ C. F. DOANE, \\ Assistant Dairyman, Dairy Division.
}

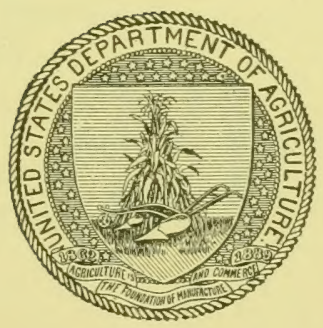

WASHINGTON :

GOVERNMENT PRINTING OFFICE.

1910.

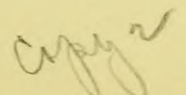




\section{THE BUREAU OF ANIMAL INDUSTRY.}

Chief: A. D. MeLvin.

Assistant Chief: A. M. FARrington.

Chief Clerk: Charles C. Carroll.

Animal Husbandry Division: George M. Rommel, chief.

Biochemic Division: M. Dorset, chief.

Dairy Division: B. H. RAWL, chief.

Inspection Division: Rice P. Steddom, chief; Morris Wooden, R. A. Ramsay, and Albert E. Behnke, associate chiefs.

Pathological Division: JoHn R. MoHLer, chief.

Quarantine Division: Richard W. HickMan, chief.

Zoological Division: B. H. Ransom, chief.

Experiment Station: E. C. SCHROEdER, superintendent.

Editor: James M. Pickens.

2

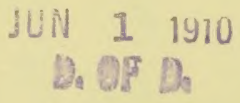




\section{LETTER OF TRANSMITTAL.}

U. S. Department of Agriculture,

Bureau of Animal Industry,

Washington, D. C., March 14, 1910.

SIR: I have the honor to transmit the accompanying manuscript of an article entitled "The Influence of Lactic Acid on the Quality of Cheese of the Cheddar Type," by C. F. Doane, of the Dairy Division of this Bureau. Mr. Doane has for some time been stationed at one of the principal cheese-making centers of the country, carrying on work connected with the manufacture and storage of cheese under practical conditions. The experiments described in the present paper have resulted in establishing data which are contrary to the usual practice of factories producing the Cheddar type of cheese, and are therefore calculated to be of value to this section of the cheesemaking industry. I recommend the publication of the article in the bulletin series of this Bureau.

Very respectfully,

Hon. James Wilson,

A. D. Melvin, Chief of Bureau.

Secretary of Agriculture. 


\section{O N T E N TS.}

5

Lactic-acid problems in cheese making........................... 5

Effect of high acidity on quality of storage cheese.................. 11

Experimental work to test effect of acid on flavor.................... 14

Results of experiments contrary to general practice............... 16

The use of starter in milk.................................... 18

Effect of early storage on acid cheese......................... 18

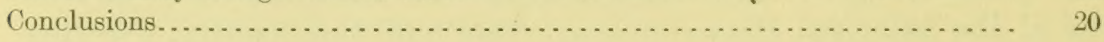

\section{L L US T R A T I O NS.}

FIG. 1. Diagram showing relation of acidity to score of cheese at various periods

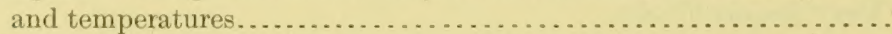

2. Diagram showing relation of acidity to score of high-acid and normal

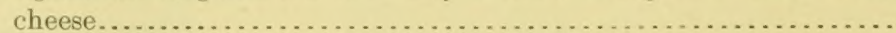

Page. 


\section{THE INFLUENCE OF LACTIC ACID ON THE QUALITY OF CHEESE OF THE CHEDDAR TYPE.}

INTRODUCTION.

The relation of lactic acid to the science of cheese making, particularly its action under varying conditions, and the necessity, or otherwise, for its development during the process of manufacture, are among the greatest unsolved problems connected with the dairy industry.

In the making of the Cheddar type of cheese at the present time the expert cheese maker is chiefly concerned with this development of lactic acid, and his entire ability is exerted to secure a uniformity of cooking with the development of the acid. This is desired because it is believed that a maximum quantity of acid is necessary for the best results. This maximum development is determined by the amount of acid that the curd will stand in the whey at the time of drawing the latter without subsequent injury to the texture and the color of the cheese. The best cheese makers are agreed, almost without exception, that on this development of acid depends to a great extent the delicate flavor that the best cheese should have, also, the desired closeness of body, as well as some of the qualities of texture found in the best cheese. Under the present conditions, therefore, there is ample opportunity for the exhibition of skill in handling the milk and the curd, since the attainment of even a small degree of success in securing uniformity of the different processes under varying conditions comes only with long practice and keen observation.

\section{LACTIC-ACID PROBLEMS IN CHEESE MAKING.}

There is undoubtedly much yet to be learned concerning the development of lactic acid and its effects in cheese making. One apparent inconsistency lies in the differing effects of the lactic acid which is developed before, as compared with that which is developed after, the whey is drawn. It it well known that the development of acid in the whey beyond approximately 0.2 per cent will 
result in an acid cheese, although a slight variation from this will depend upon whether the milk is working fast or slow. A high-acid condition has a decidedly injurious effect on the texture and the color of the cheese, and the greater the development of acid in the whey beyond the above limit the more pronounced is the injury. On the other hand, after the whey is drawn and the curd is put on the rack, the acid may develop until the expressed whey shows a full 1 per cent, or even more, without any injury to texture or color. This would certainly appear to be inconsistent. In both cases the acid formed is evidently lactic acid. In both cases the acid is formed inside of the curd particles, as the greater part of the bacteria are carried down into the curd after setting the milk and cutting the curd, ${ }^{a}$ and the acid is formed in the curd and expelled into the whey. We have, then, in each case a process of acid formation operating under such similar conditions as to be apparently identical, yet the results are radically different. While in the whey a development of 0.3 per cent of lactic acid will practically ruin the commercial value of the cheese, yet in the matted curd more than three times this quantity may develop with what most cheese makers believe to be a benefit, and certainly without apparent injury.

In the best present-day practice in cheese making there is an attempt to develop all the acid possible without injury to the texture and color of the product. To begin with, a maximum amount of acid is developed in the whey, and finally the curd is allowed to remain on the rack until all the acid that will develop in a practicable length of time is obtained. But while there are many positive opinions in regard to the good results of this method, there is but little accurate knowledge. The effect of acid on flavor is not known, and, contrary to general opinion, a glance at some of the tables included in this paper will show that a flat or low flavor may be found in a high-acid cheese. Again, the actual effects of a so-called proper development of acid on the closeness or the texture of the cheese is not known. The desired characteristics of texture, body, and flavor may be found, and have been found on numberless occasions, when the curd has been worked through comparatively sweet.

However, we know beyond doubt that a high acid development in the whey will injure the resulting product. Furthermore, we have very good reason to believe that a high acid development in the curd made from so-called gassy milk is necessary to overcome the gas, and it may at the same time prevent a full development of the undesirable flavors attending gassy curds.

a J. L. Sammis. Factors controlling the moisture content of cheese curds. U. S. Department of Agriculture, Bureau of Animal Industry, Bulletin 122. 


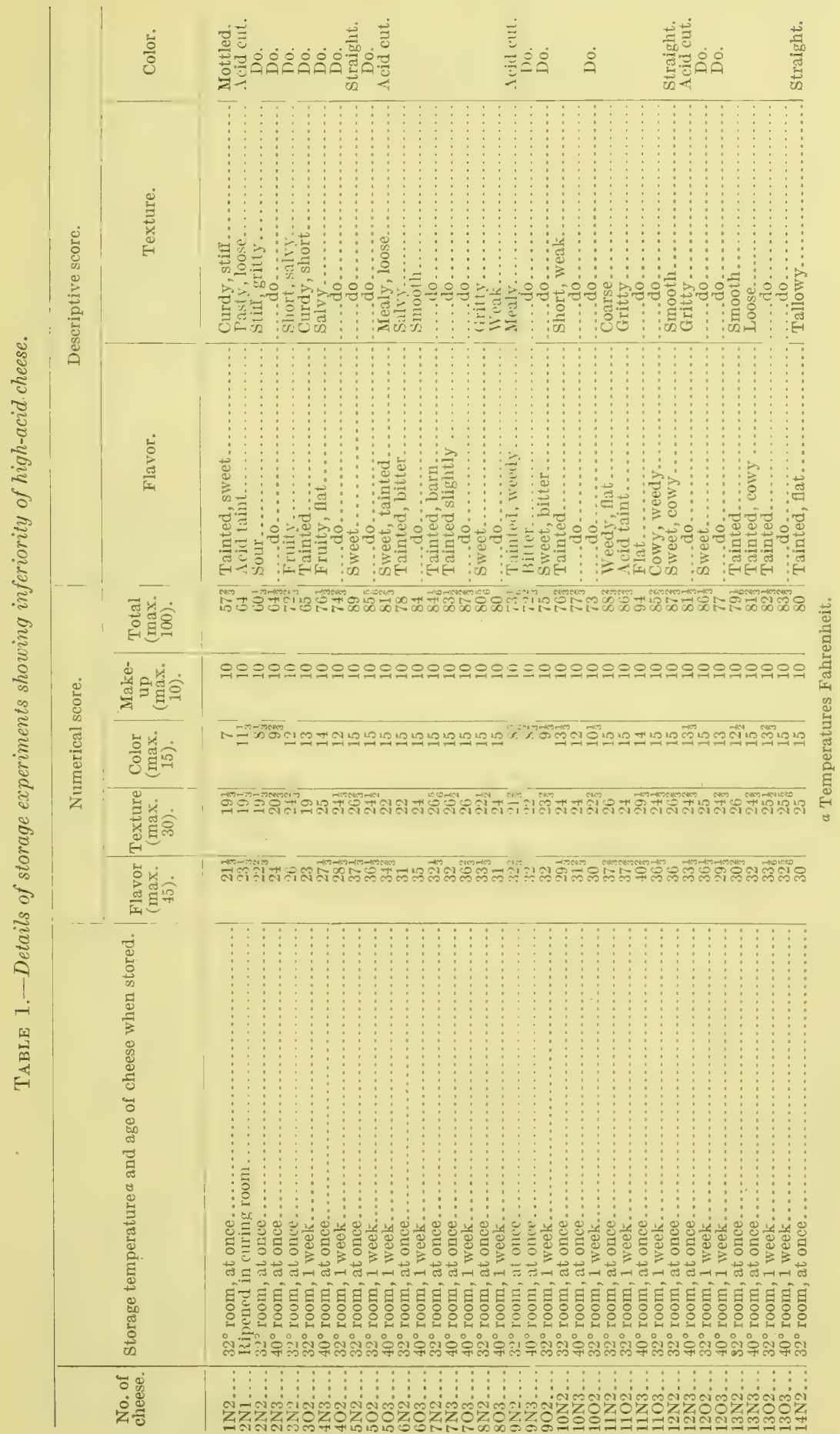




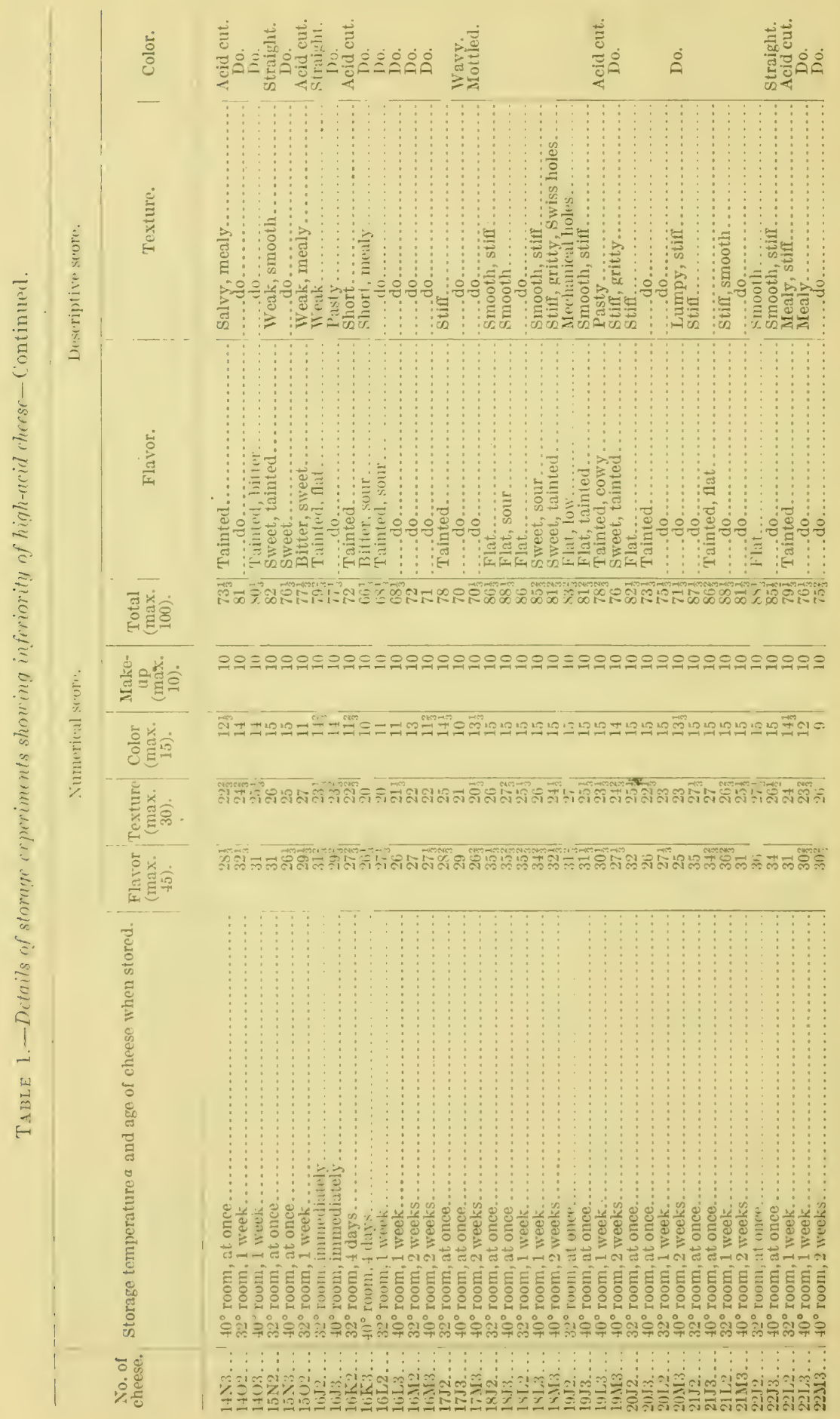


ஷ்

o

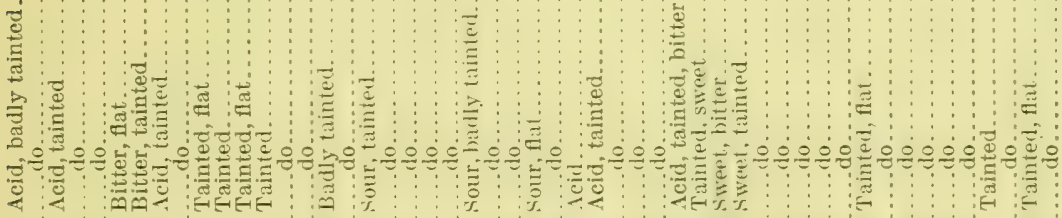

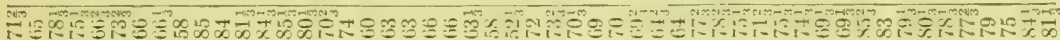

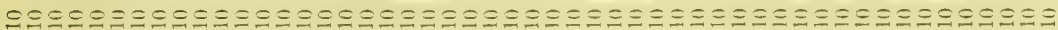

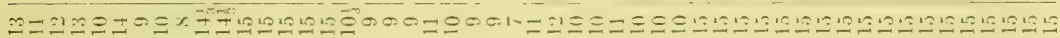

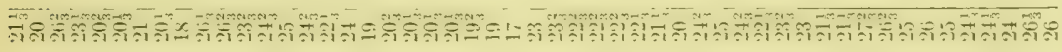

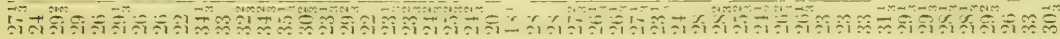

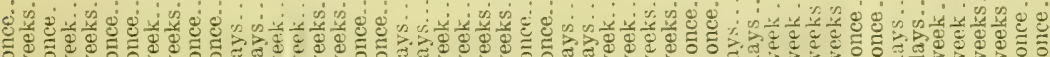

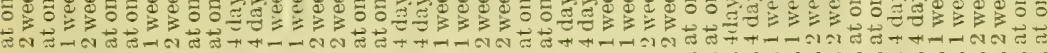

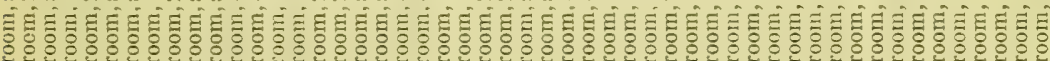

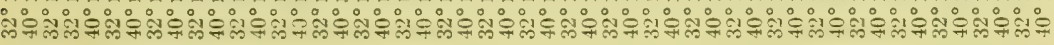
ง

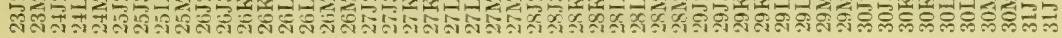
35824-Bull. 123-10-2 


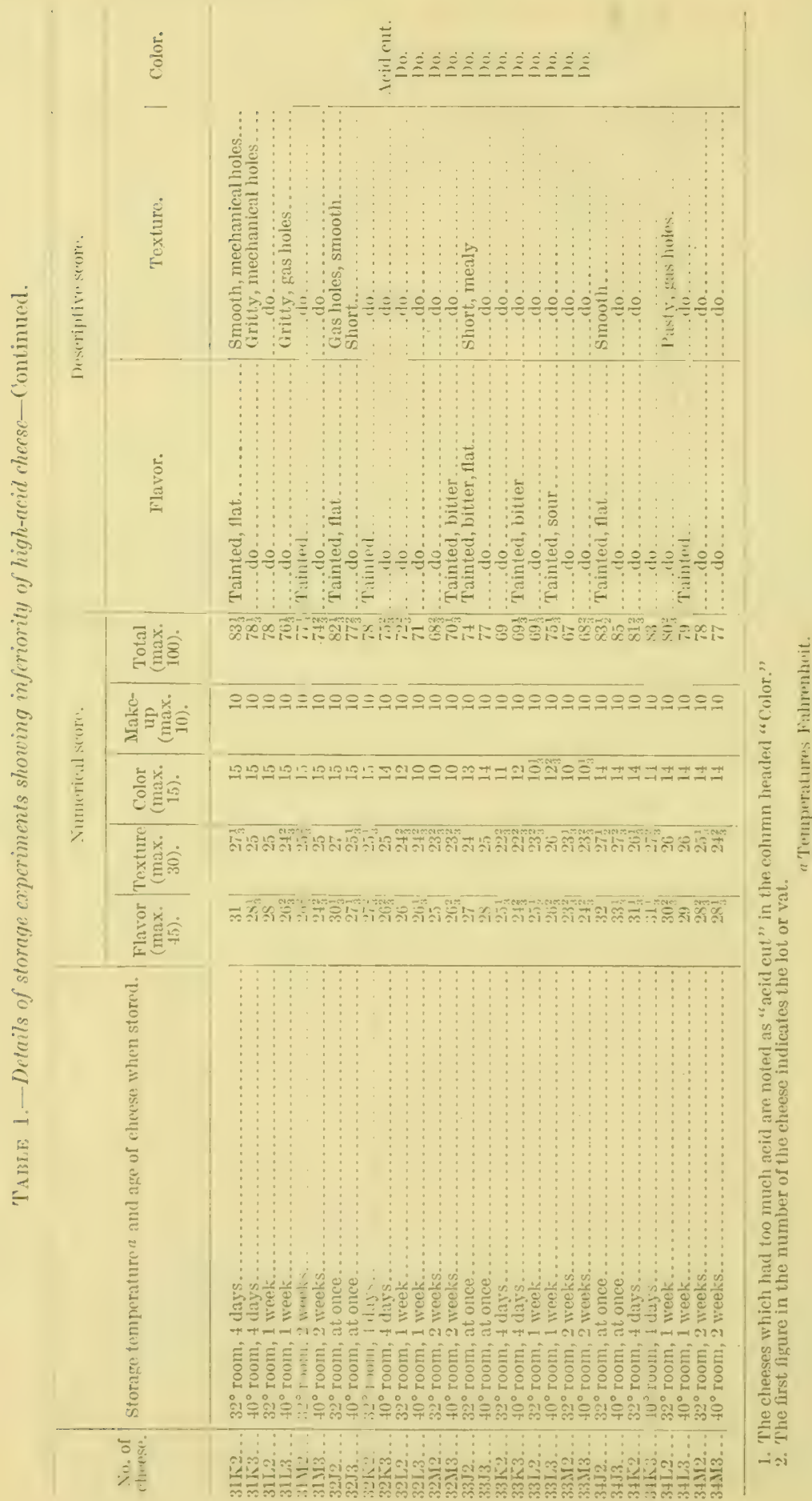




\section{EFFECT OF HIGH ACIDITY ON QUALITY OF STORAGE CHEESE.}

The attention of the writer was called to one phase of this acid question at the time of seoring the cheese in the storage experiments made in the summer of 1906 . A representative of the Dairy- Dirision visited a number of cheese factories near Plymouth. Wis., that were having trouble with their product, and secured a quantity of cheese for storage. Most of these lots of cheese turned out to be high aridl. and it was noted that where this was the case the quality was so rery low as to make it appear that the acid was responsible in part at least for the poor flavor, as well as for the other undesirable characteristics always found in a high-acid cheese.

The cheese in cuestion was obtained for the purpose of determining the eflect of storage on different kinds of poor cheese. It was purchased in July and Augnst and was scored in January. The scores are given in Table 1. Because of the larege proportion of this cheese that turned out to be high acid the work as planned was not satisfactory, but it did show the tendeney to make high-acid cheese when troubles with bad milk are experienced, and it illustrated very well the probable effect of high acid on the quality of the product. There were $3 t$ lots of the cheese, ench consisting of $s$ cheeses, one-half of which were stored in the $32^{\circ} \mathrm{F}$. room at various periods ranging up to two weeks, the other half being similarly placed in the $40^{\circ}$ F. room. The average score on flavor for the high-acid cheese was 27 , while the arerage on the normal acid cheese was 31 . The comparatively poor flavor of all the high-acid cheese was so marked that all who were connected with the seoring of this cheese noticed it and commented upon it.

The Dairy Division made some high-acid cheese in the summer of 1906 to determine the effects of storage on this quality of product. The cheese was made from exceptionally good milk, and the flaver should have been, in some of the lots at least, above criticism. Nine lots of cheese were made with varying amounts of acid. Quite a wide variation in the perentages of acid was sought, especially at the time the whey was drawn, as the degree of acidity at this period influences the quality of the cheese more than the acidity shown at any other period of its manufacture. The acid at the time of setting was regulated to suit the percentage desired at the time of drawing the whey. The percentages of acid at different stages of mamufacture are shown in Table 3.

Eight cheeses were made in each lot. These were stored two at a time-one at $32^{\circ} \mathrm{F}$. and the other at $40^{\circ} \mathrm{F}$. - at each of the following periods: Fresh from the press, four dars old, one week old, and two weeks old. All the cheese was scored by three judges working independently, and Table 2 gives the average sores. Table $t$, abstracted 


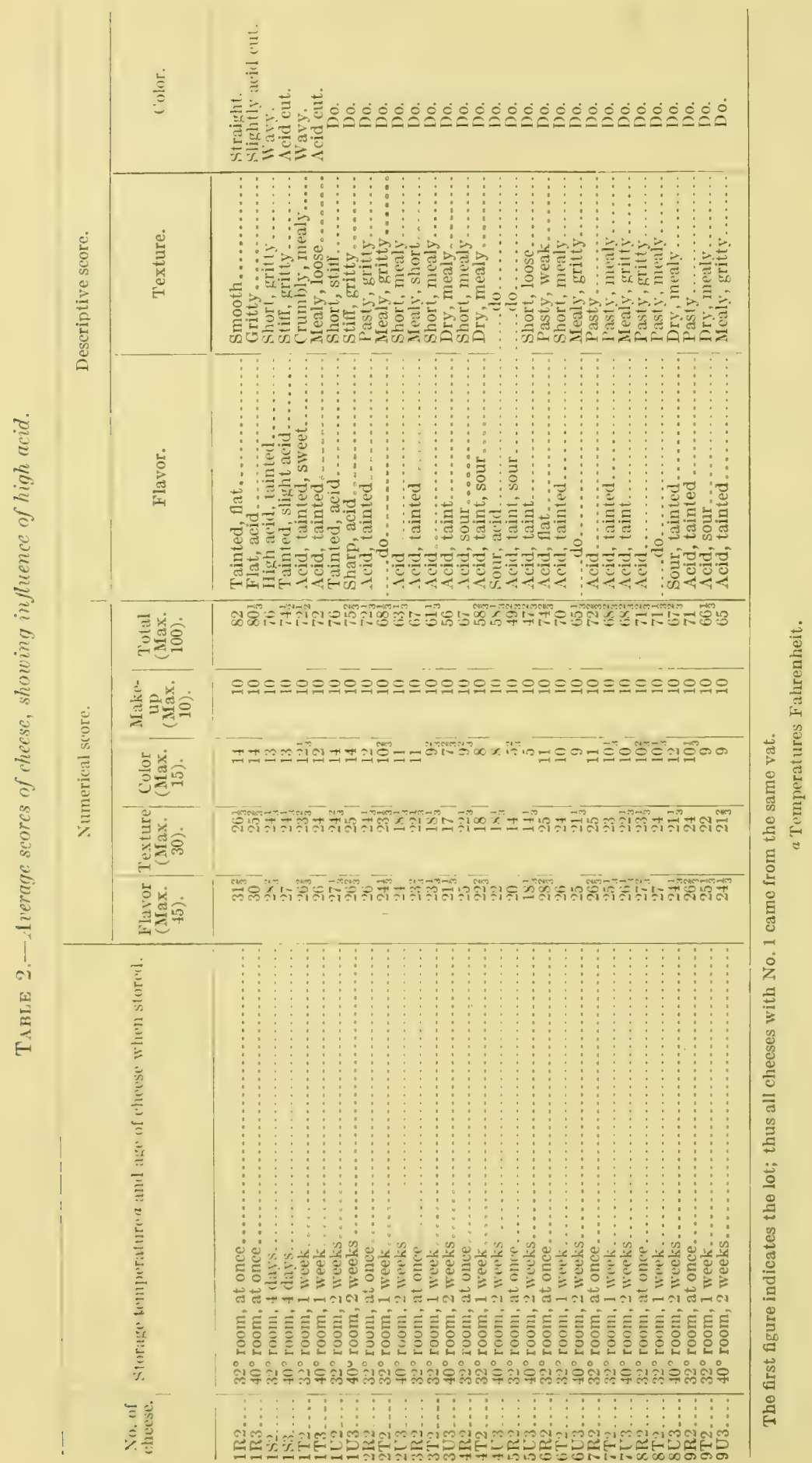


from Table 2, and figure 1 are arranged to show more clearly the relation of the numerical score to the acidity. Not all the scores are given, but those omitted are in line with those given. Enough are given to show conclusively the eflect of the high acid on the cheese.

TABLE 3.-Acidity at stated periods of high-acid cheese used in storage experiments and scored in Table 2.

\begin{tabular}{|c|c|c|c|}
\hline $\begin{array}{l}\text { No. of } \\
\text { lot. }\end{array}$ & $\begin{array}{c}\text { Acidity } \\
\text { when } \\
\text { set. }\end{array}$ & $\begin{array}{l}\text { Acidity } \\
\text { when } \\
\text { cut. }\end{array}$ & $\begin{array}{c}\text { Acidity } \\
\text { when } \\
\text { drawn. }\end{array}$ \\
\hline $\begin{array}{l}1 \ldots \ldots \\
2 \ldots \ldots \\
3 \ldots \ldots \\
4 \ldots \ldots \\
5 \ldots \ldots \\
6 \ldots \ldots \\
7 \ldots \ldots \\
8 \ldots \ldots \\
9 \ldots \ldots\end{array}$ & $\begin{array}{r}\text { Percent. } \\
0.175 \\
.175 \\
.185 \\
.195 \\
.260 \\
.200 \\
.175 \\
.1 \pm 3 \\
.170\end{array}$ & 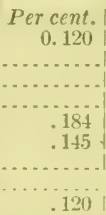 & $\begin{array}{c}\text { Per cent. } \\
0.207 \\
.329 \\
.240 \\
.215 \\
.303 \\
.225 \\
.220 \\
.211 . \\
.220\end{array}$ \\
\hline
\end{tabular}

TABLE 4.-Relation of the numerical score to the acidity of cheese described in Table 2.

\begin{tabular}{|c|c|c|c|c|c|c|c|c|c|c|}
\hline \multirow{2}{*}{$\begin{array}{l}\text { Num- } \\
\text { ber } \\
\text { of lot. }\end{array}$} & \multicolumn{4}{|c|}{$32^{\circ}$ room, at once. } & \multicolumn{3}{|c|}{$32^{\circ}$ room, one week. } & \multicolumn{3}{|c|}{$40^{\circ}$ room, two weeks. } \\
\hline & ity. & Flavor. & $\begin{array}{l}\text { Tex- } \\
\text { ture. }\end{array}$ & Total. & Flavor. & $\begin{array}{l}\text { Tex- } \\
\text { ture. }\end{array}$ & Total. & Flavor. & $\begin{array}{l}\text { Tex- } \\
\text { ture. }\end{array}$ & Total. \\
\hline $\begin{array}{l}1 \\
8 \\
4 \\
7 \\
9 \\
6 \\
2 \\
3 \\
5\end{array}$ & $\begin{array}{l}\text { Perct. } \\
0.207 \\
.211 \\
.215 \\
.220 \\
.220 \\
.225 \\
.229 \\
.240 \\
.303\end{array}$ & $\begin{array}{l}31_{3}^{2} \\
27 \frac{2}{3} \\
25^{2} \\
26 \frac{2}{3} \\
26 \frac{2}{3} \\
28_{3}^{2} \\
26 \frac{1}{3} \\
23^{\frac{2}{3}} \\
20\end{array}$ & $\begin{array}{l}263 \\
231 \\
222_{3}^{1} \\
25 \\
24 \\
253 \\
243 \\
223 \\
14\end{array}$ & $\begin{array}{l}82 \\
71 \frac{2}{3} \\
67 \\
72 \frac{2}{3} \\
71 \\
74 \frac{2}{3} \\
72 \frac{1}{3} \\
67 \\
49 \frac{2}{3}\end{array}$ & $\begin{array}{l}26 \frac{2}{3} \\
27 \\
22 \frac{2}{3} \\
25 \frac{1}{3} \\
25 \frac{1}{3} \\
26 \\
24_{3}^{\frac{1}{3}} \\
23 \frac{1}{3}\end{array}$ & $\begin{array}{l}232 \\
24 \\
18 \\
23 \\
22 \\
24 \\
23 \frac{1}{3} \\
18 \frac{1}{3}\end{array}$ & $\begin{array}{l}72 \frac{2}{3} \\
71 \frac{3}{3} \\
58 \frac{2}{3} \\
688_{3}^{2} \\
66 \frac{1}{3} \\
70 \\
68 \frac{1}{3} \\
61 \frac{1}{3}\end{array}$ & $\begin{array}{l}26 \frac{2}{3} \\
24 \frac{1}{3} \\
22 \\
26 \frac{1}{3} \\
24 \frac{1}{3} \\
25 \\
26 \frac{2}{3} \\
21 \frac{1}{3} \\
18 \frac{1}{3}\end{array}$ & $\begin{array}{l}25 \\
21 \frac{1}{3} \\
18 \frac{1}{3} \\
22 \frac{1}{3} \\
21 \frac{2}{3} \\
21 \frac{1}{3} \\
18 \frac{1}{3} \\
17 \\
14 \frac{1}{3}\end{array}$ & $\begin{array}{l}75_{3}^{2} \\
67 \frac{2}{3} \\
58 \frac{1}{3} \\
68^{2} \\
65 \\
65 \frac{1}{3} \\
63 \frac{1}{3} \\
56 \\
47 \frac{2}{3}\end{array}$ \\
\hline
\end{tabular}

It has already been stated that the above cheese was made as far as could be judged from perfect milk and that the curds worked through in excellent shape. It least a few cheeses should have been of excellent quality; but it appears that the quality was injured in about the same proportion as the amount of acid developed. The cheese in lot 1 was made with acid very slightly in excess of normal, and the cheese from this lot that was placed in the $3: 2^{\circ}$ room at once scored 8.2 , while the similarly treated cheese in lot 5 was made with much too high a development of acid and scored a fraction less than 50. It is probable that cheese made from good milk would never score as low as 50 points or as low as 20 points in flaror if it had been treated normally in all stages of making and curing. Hence it would appear very probable that the high-acid development was responsible in part, at least, for the poor flavor. These results were so contrary to all belief and teaching that it was thought desirable to make some 
aceurate comparative tests that would settle the question berond controversy. For this purpose the author spent some time at a factory near Plymouth, Wis., and carried out the experiments described in the following pages.

\section{EXPERIMENTAL WORK TO TEST EFFECT OF ACID ON FLAVOR.}

Sixteen lots of cheese were mate for these experiments. Two lots were made each day from vats of divided milk so as to have identical conditions as regards quality of milk. One of these lots was worked up with just suffieient acid in the whey to make a light-acid cheese, the other lot being worked up on the same day in the regular way for that factory. The cheese maker in charge of this factory set his

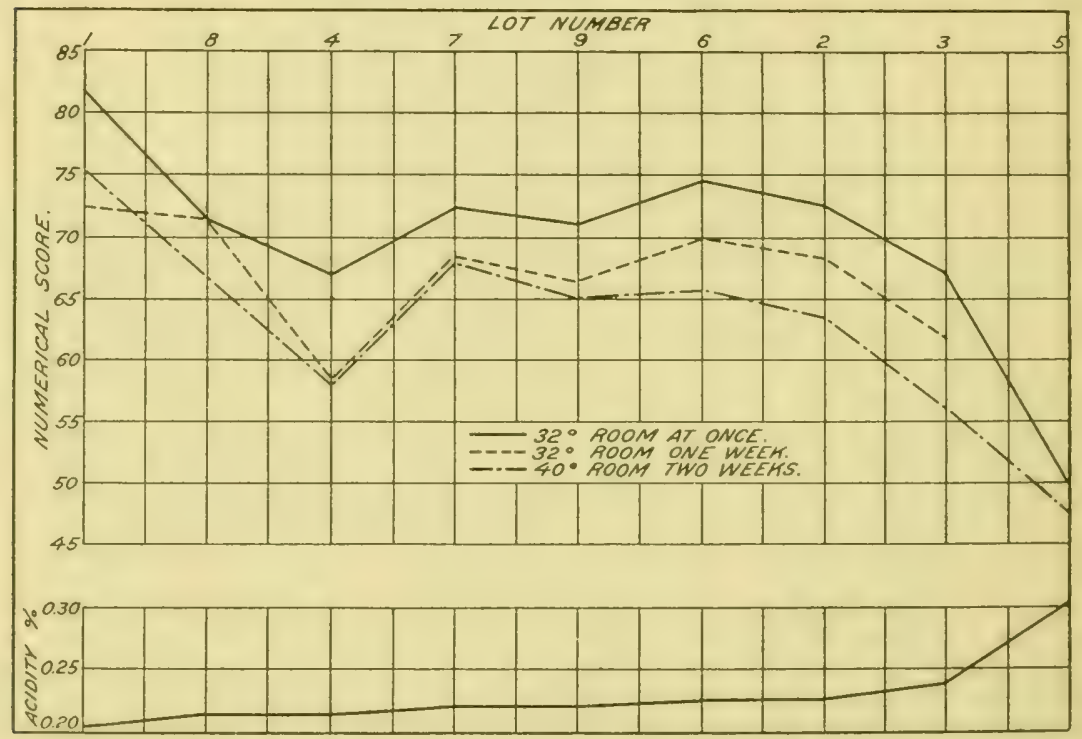

FIG. 1,-Diagram showing relation of acility to score of checse at various periods and temperatures.

milk and drew the whey some what sweeter than is customary among the best eheeese makers: but the curd was allowed to develop the acid on the rack until all dinnger of gras had passed. Table 5 show's some of the details of the manufacture of each lot.

The eheese wis made during the first half of september, 1907, and each lot was helel in the factory curing room one week before being placed in storage. The storage room was held at about $333^{\circ} \mathrm{F}$. The cherese was secored in the midlle of Jamuary, 190s, by J. W. Moore and Robert Mc Adam, of the Dairy Division, both experienced eheese maliers and judges. The averace seore of each cheese is shown in Table fi, and the relation of the numerieal seore to the acidity is graphically shown in figure 2. 
TABLE 5.-Details of manufacture of cheese for test of high acid on flavor.

\begin{tabular}{|c|c|c|c|c|c|c|c|c|}
\hline Lot. & $\begin{array}{l}\text { Time } \\
\text { set. }\end{array}$ & $\begin{array}{l}\text { Acidity } \\
\text { when } \\
\text { set. }\end{array}$ & $\begin{array}{l}\text { Time } \\
\text { cut. }\end{array}$ & $\begin{array}{c}\text { Time } \\
\text { drawn. }\end{array}$ & $\begin{array}{c}\text { Acidity } \\
\text { when } \\
\text { drawn. }\end{array}$ & $\left|\begin{array}{c}\text { Curd } \\
\text { ground. }\end{array}\right|$ & $\begin{array}{c}\text { Curd } \\
\text { salted. }\end{array}$ & Remarks. \\
\hline 1 , acid.... & $\begin{array}{r}a . m . \\
7.52\end{array}$ & $\begin{array}{c}\text { Per cent } . \\
0.17\end{array}$ & $\begin{array}{l}a . m \text {. } \\
8.25\end{array}$ & $\begin{array}{l}a . m . \\
11.00\end{array}$ & $\begin{array}{c}\text { Percent. } \\
0.23\end{array}$ & p. $m$. & $\begin{array}{c}p . m . \\
1.40\end{array}$ & furd firm; few pin holes; bad \\
\hline 1, sweet.. & 7.45 & .17 & 8.25 & 10.00 & .17 & 12.30 & 2.15 & Numerous pin holes; bad flavor, \\
\hline 2 , acid.. & 8.30 & .20 & 8.50 & 9.55 & .20 & 12.20 & 1.30 & Good curd. \\
\hline acid. & 7.20 & .17 & 7.55 & 9.15 & .15 & 12.30 & 1.30 & Do. \\
\hline $\begin{array}{l}3 \text {, acid.... } \\
3 \text {, sweet.. }\end{array}$ & 8.10 & .20 & 8.30 & 9.55 & .20 & 11.45 & 12.30 & Good curd; slight taint. \\
\hline sweet.. & 7.40 & .175 & 8.20 & 9.45 & .16 & 12.00 & 12.30 & Few pin holes; slight taint. \\
\hline $\begin{array}{l}4 \text {, acid.... } \\
4, \text { sweet.. }\end{array}$ & 7.50 & .20 & 8.20 & 9.35 & .21 & 12. 05 & 1.00 & Gassy. \\
\hline $\begin{array}{l}\text { 4, sweet.. } \\
5 \text {, acid... }\end{array}$ & $\begin{array}{r}7.40 \\
10\end{array}$ & .17 & 8.20 & 9.45 & .18 & 12.45 & 1.30 & Do. \\
\hline $\begin{array}{l}\text { acid....- } \\
\text { sweet.. }\end{array}$ & $\begin{array}{r}10.00 \\
8.50\end{array}$ & .20 & 10.20 & 11.55 & .21 & 2.20 & 3.30 & Slight taint; pin holes. \\
\hline ac & $\begin{array}{l}8.00 \\
8.40\end{array}$ & .18 & $\begin{array}{l}8.45 \\
9.02\end{array}$ & $\begin{array}{l}10.40 \\
10.45\end{array}$ & $\begin{array}{l}.16 \\
.20\end{array}$ & $\begin{array}{l}1.00 \\
1.00\end{array}$ & $\begin{array}{l}2.30 \\
2.15\end{array}$ & $\begin{array}{l}\text { Do. } \\
\text { Do. }\end{array}$ \\
\hline 6 , swee & 8. 00 & .19 & 8.30 & 10.30 & .16 & 12.40 & 2.00 & Do. \\
\hline 7, acio & 8.52 & .20 & 9.15 & 10. & .20 & 1.00 & 2.00 & Slight taint. \\
\hline & 8.10 & .18 & 8.50 & 10. & .1 & 2.00 & 3.00 & Slight taint; few pin holes \\
\hline 8 & 9.20 & .145 & 9.40 & 11. & .1 & 1.3 & 2.30 & Slight taint; pin holes. \\
\hline 8, sw & 7.45 & & 8.32 & 10.45 & .16 & 1.15 & 2.00 & \\
\hline
\end{tabular}

TABLE 6.-Average scores of cheese described in. Table 5.

\begin{tabular}{|c|c|c|c|c|c|c|c|c|c|}
\hline \multirow[b]{2}{*}{ Lot. } & \multicolumn{6}{|c|}{ Numerical score. } & \multicolumn{3}{|c|}{ Descriptive score. } \\
\hline & 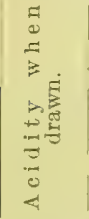 & 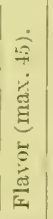 & 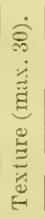 & 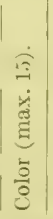 & 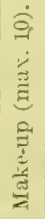 & 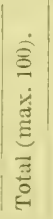 & Flavor. & Texture. & Color. \\
\hline $\begin{array}{l}1, \text { acid..... } \\
1 \text {, sweet... } \\
2 \text {, acid..... } \\
2, \text { sweet... } \\
3 \text {, acid.... }\end{array}$ & $\begin{array}{r}\text { Per ct. } \\
0.23 \\
.17 \\
.20 \\
.15 \\
.20\end{array}$ & $\begin{array}{l}35 \frac{1}{2} \\
39 \\
34 \\
39 \\
33 \frac{1}{2}\end{array}$ & $\begin{array}{l}23 \frac{1}{2} \\
28 \\
24 \frac{1}{2} \\
27 \frac{1}{2} \\
23\end{array}$ & $\begin{array}{l}13 \frac{1}{2} \\
15 \\
13 \frac{1}{4} \\
15 \\
13 \frac{1}{4}\end{array}$ & $\begin{array}{l}10 \\
10 \\
10 \\
10 \\
10\end{array}$ & $\begin{array}{l}82 \frac{1}{2} \\
92 \\
81_{4}^{\frac{3}{4}} \\
91^{\frac{1}{2}} \\
79 \frac{3}{3}\end{array}$ & $\begin{array}{l}\text { Sour whey, sweet... } \\
\text { Sweet............ } \\
\text { Sour, bitter, unclean. } \\
\text { Unclean............. } \\
\text { Very unclean, sweet, } \\
\text { sour whey. }\end{array}$ & $\begin{array}{l}\text { Coarse, mealy, stiff. } \\
\text { Mechanical holes... } \\
\text { Short, pasty, mealy. } \\
\text { Mechanical holes... } \\
\text { Crumbly, mealy.... }\end{array}$ & \begin{tabular}{|l|} 
Acid cut. \\
Straight. \\
Acid cut. \\
Straight. \\
Acid cut.
\end{tabular} \\
\hline $\begin{array}{l}3, \text { sweet... } \\
4 \text {, acid.... } \\
4 \text {, sweet... } \\
5 \text {, acid.... }\end{array}$ & $\begin{array}{l}.16 \\
.21 \\
.18 \\
.21\end{array}$ & $\begin{array}{l}39 \frac{3}{4} \\
37 \frac{1}{2} \\
39 \frac{3}{4} \\
36\end{array}$ & $\begin{array}{l}27 \frac{1}{4} \\
24 \frac{3}{4} \\
27 \frac{3}{4} \\
25\end{array}$ & $\begin{array}{l}15 \\
13 \frac{1}{2} \\
15 \\
13 \frac{3}{4}\end{array}$ & $\begin{array}{l}10 \\
10 \\
10 \\
10\end{array}$ & $\left|\begin{array}{l}92 \\
85 \frac{1}{4} \\
92 \frac{1}{2} \\
84^{\frac{3}{4}}\end{array}\right|$ & $\begin{array}{l}\text { sour whey. } \\
\text { Trifle sweet......... } \\
\text { Unclean, sweet..... } \\
\text { Sweet............ } \\
\text { Sour whey, bitter, } \\
\text { sweet. }\end{array}$ & $\begin{array}{l}\text { Coarse............. } \\
\text { Short, mealy } \\
\text { Coarse................ } \\
\text { Crumbly, mealy, }\end{array}$ & $\begin{array}{l}\text { Straight. } \\
\text { Acid cut, slightly. } \\
\text { Straight. } \\
\text { Acid cut. }\end{array}$ \\
\hline $\begin{array}{l}5, \text { sweet... } \\
6 \text {, acid.... }\end{array}$ & $\begin{array}{l}.16 \\
.20\end{array}$ & $\begin{array}{l}39 \frac{1}{4} \\
34 \frac{1}{2}\end{array}$ & $\begin{array}{l}27 \\
24\end{array}$ & $\begin{array}{l}15 \\
12 \frac{1}{4}\end{array}$ & $\begin{array}{l}10 \\
10\end{array}$ & $\begin{array}{l}91 \frac{1}{4} \\
81 \frac{1}{4}\end{array}$ & $\begin{array}{l}\text { Slightly sweet ...... } \\
\text { Sour whey, bitter, } \\
\text { sweet. }\end{array}$ & $\begin{array}{l}\text { Uneven............ } \\
\text { Mealy, soggy...... }\end{array}$ & $\begin{array}{l}\text { Straight. } \\
\text { Acid cut. }\end{array}$ \\
\hline $\begin{array}{l}6, \text { sweet... } \\
7 \text {, acid.... }\end{array}$ & .16 & $\left|\begin{array}{l}38 \frac{1}{2} \\
36 \frac{1}{4}\end{array}\right|$ & $\begin{array}{l}27 \frac{3}{4} \\
26 \frac{1}{2}\end{array}$ & \begin{tabular}{|c|}
$14 \frac{3}{4}$ \\
14
\end{tabular} \mid & $\begin{array}{l}10 \\
10\end{array}$ & $\begin{array}{l}91 \\
86 \frac{3}{4}\end{array}$ & $\begin{array}{l}\text { Sweet. } \\
\text { whe y, bitter, } \\
\text { sweet. }\end{array}$ & $\begin{array}{l}\text { Uneven........... } \\
\text { Short, mealy...... }\end{array}$ & $\begin{array}{l}\text { Slightly faded. } \\
\text { Acid cut. }\end{array}$ \\
\hline $\begin{array}{l}\text { 7, sweet... } \\
8 \text {, acid.... } \\
8, \text { sweet... }\end{array}$ & $\begin{array}{l}.18 \\
.19 \\
.16\end{array}$ & $\left|\begin{array}{l}38 \frac{3}{4} \\
36 \frac{1}{1} \\
35_{\frac{3}{4}}^{\frac{3}{4}}\end{array}\right|$ & $\begin{array}{l}27 \frac{1}{4} \\
25 \frac{1}{2} \\
28 \frac{1}{1}\end{array}$ & $\begin{array}{l}15 \\
14 \\
15\end{array}$ & $\begin{array}{l}10 \\
10 \\
10\end{array}$ & $\begin{array}{l}91 \\
86 \\
92\end{array}$ & $\begin{array}{l}\text { Tainted, sweet...... } \\
\text { Sour, bitter, sweet.. }\end{array}$ & $\begin{array}{l}\text { Weak } \\
\text { Crumbly, mealy.... }\end{array}$ & $\begin{array}{l}\text { Straight. } \\
\text { Acid cut. } \\
\text { Straight. }\end{array}$ \\
\hline
\end{tabular}

Average score on flavor of cheese made with normal acid, 39.

Average score on flavor of cheese made with high acid, 35.5 .

As will be noted from Table 6 , the milk was not perfect at any time during which the experimental cheese was made, neither was it very bad, and there was no difficulty in making a cheese that commanded full market price. There was a slight taint, also a few pin holes that worked out easily in the matted curd. It was perhaps unfortunate in some respects that the milk was not perfect for a few of the lots. 
But the results of the experiment are so positive that it can not be considered otherwise than conclusive.

A study of the numerical and descriptive scores in Table 6 shows that high acid has a markedly injurious influence on the flaror. The bat flavors in the cheese made up sweet were in erery case less pronounced than in that of the same lot which was made up acid. In addition other bad flarors appeared in the acid cheese that were not apparent in the cheese made normally. The sweet or fruity flaror that was noticed in all the cheese was more pronounced in the high acid than in the normal cheese of the same day. In fire out of the eight lots a bitter flavor in the acid cheese appeared that was not noticeable in the normal cheese of the same day. A sour or old whey flavor appeared in most of the high-acid cheese.

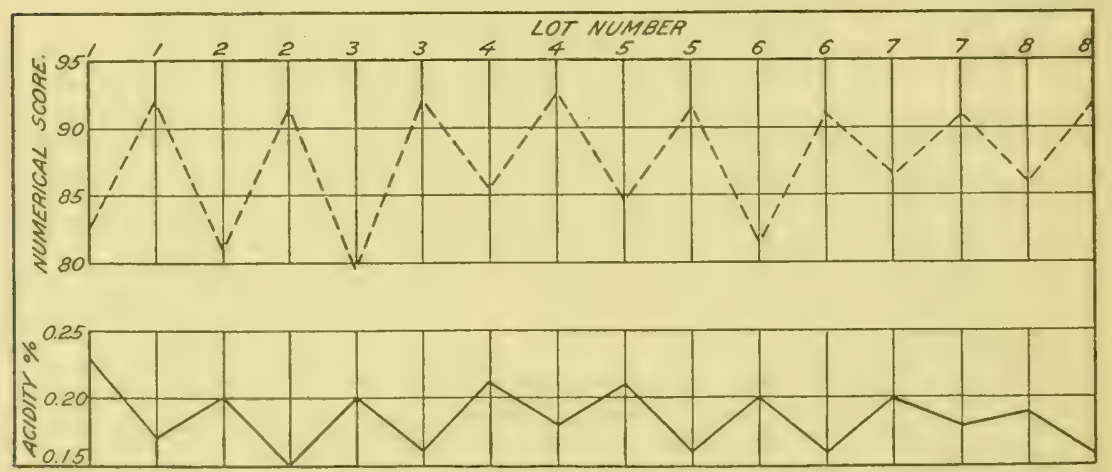

FIG. 2.-Diagram showing relation of acidity to score of high-acid and normal cheese.

\section{RESULTS OF EXPERIMENTS CONTRARY 'TO GENERAL PRACIICE,}

These results are certainly very radical in riew of the belief of cheese makers and the teaching of experts to the contrary. The great majority of cheese makers believe that a high development of acid is an antidoter for had flavors of all kinds, and that it is about the only means they have of fighting had flavors als well ats gats. Whenever a period of bad milk comes and the product is off flarored or gassy, the eflort hats always been made to develop a maximum of acid in the whey as a preventive of the trouble. It has, in fact, usually been considered andrisable, where the trouble has been pronounced, to make a slightly high-aleid cheese, as the high acid hats been comsidered the less of the two evils. This practice is taught by dairy instructors and reconmended by many cheese dealers who act as alvisers to the chese makers from whom they buy. The result hats ustally been that alter a few lots of poor cheese were made at a litetory a period of high-acid eheese followed. The foregroing experi- 
ments prove that this tendency to develop excessive acid is poor policy. In fact, insteal of minimizing the faults it makes them more pronounced, as well as adding new faults to the product.

It is universally believed and taught that a maximum development of acid in the whey is necessary for a satisfactory and maximum development of acisl in the matted curd. Dean ${ }^{a}$ in some of his work, seemed to show that the curl was ready for grinding and for the press at the same time regardless of the percentage of acility at which the milk was set or the whey drawn, vats of divided milk being used for the experiments. In riew of the fact that the bacteria are held within the curd particles and the acid is consequently developed in the curd, we have no reason to believe that this development would not go on as fast in the matted curd as in the whey.. This would appear to be much more reasonable than the old idea that a maximum development of acid in the whey was necessary to hurry the process.

While a high acility is needed to exclurle undesirable forms of bacteria and give the cheese its desired characteristics, this high acidity can develop) in the matted curd. That there is no virtue in a high development of acid in the whey can be seen from Table 5 . The taint and the gas were as bad in the curd allowed to remain in the whey until a high acid was developed as they were in the curds from the comparatively sweet whey. The development of high acid in the whey did not have any effect on the growth of injurious bacteria, as far as could be judged from the product. The maximum amount of acid in the whey at time of drawing is about 0.2 per cent, and this is generally considered to be insufficient to check most of the injurious bacteria. It is the comparatively high-acid development which takes place in the matted curd that holds these bacteria in check.

From all this evidence there is but one conclusion to be drawn, namely, that the teaching which led to a maximum development of acid in the whey was wrong. The high acid developed in the whey is likely to cause much injury, and from the evidence at hand it does no good. With our present knowledge, however, it can hardly be advised to go to the other extreme and run the whey as sweet as possible, but it is certainly evident that the whey should be run sufficiently sweet to leare no possibility of making a high-acid cheese.

An interesting feature of the results of the experiments shown in Tables 1 and 2 is seen in the lots where only part of the cheese turned out to be high acid. The cheeses in those lots that were placed in storage direct from the press showed no evidence of high acid, while those that remained in the factory curing room for a time before going

a Twenty-second Annual Report, Ontario Agricultural College, 1896, p. 54. 
into storage were injured in texture and color. The point in this connection lies in the fact that the cheese that was injured in texture and color was likewise injured in flaror. Whether the low score on flavor was simply coincident with the low score on texture and color and due to the longer time that the cheese was held out of storage, or whether there is some unexplained connection between the injury in texture and the injury to flavor, might seem open to question. It would appear that the former was the case in part. If the latter be true it must be considered that the point in acidity which injures the texture also injures the flavor. There are reasons to believe that this is true, or at least that the point of acidity at which the flaror is injured and the point at which the texture is injured are not very far apart.

There is therefore a question in connection with this which may be investigated with profit. Whey can be drawn with 0.2 per cent of acid without injury to the texture of the curd. Any acid above this evidently injures both texture and flavor. Does the injury to texture and to flavor begin at the same point in acidity, or does injury to flavor begin with a lower acidity than 0.2 per cent?

\section{THE USE OF STARTER IN MIIK.}

Nothing in this discussion should be interpreted as being opposed to the use of a good starter in the milk before setting. The development of acid is, according to our present knowledge on the subject, necessary to overcome the growth of gas-producing and other undesirable forms of bacteria. Bacteriological investigations have shown that if there is a sufficient number of lactic-acid bacteria as compared with the other kinds, the lactic-acid bacteria increase to the partial exclusion of many other kinds. When the lactic acid has developed to a relatively high degree it makes the milk or the curd an unfarorable place for many kinds of bacteria to grow. The starter can be added usually without any danger of increasing the acidity to a point where it will be difficult to cook to a proper degree of firmmess before too high acidity has developed in the whey.

\section{EFFECT OF EARLY STORAGE ON ACID CHEESE.}

This work may be considered a continuation of previous work carried on hy the Dairy Division at Plymouth during the summer of 1905. ${ }^{a}$ It was plamned to determine definitely some of the results which showed incidentally in the previous work. The main point which it was desired to cover was the effect of low storage temperatures on high-acid cheese.

a Bureau of Animal Industry Bulletin 85. 
In the report on the previous storage work at Plymouth attention was called to the fact that in two or three lots of cheese used in the tests the cheese which was left in the factory curing room for from one to two weeks at a temperature of from $55^{\circ}$ to $70^{\circ} \mathrm{F}$. showed decidedly too much acid, almost a so-called "dead sour" in one case. The ones from the same lots (including the dead-sour lot) which went directly from the hoop into the rooms held at $32^{\circ}$ and $40^{\circ} \mathrm{F}$. were very slightly acid, in fact showed so little evidence of too much acid that the selling price was not affected in the least. This was a decidedly interesting point, and as practically all cheese dealers held entirely opposite views, a thorough demonstration of the results obtained would be of economic importance as well as of scientific: value.

At the present time most of the cheese dealer's protest against receiving a cheese under one week of age, because in a young cheese too much acid can not be readily detected. If it can be satisfactorily shown that a cheese which does not show too much acid at the time it goes into storage will come out of storage in good condition the objection on the part of the dealers to receiving very fresh goods would be entirely overcome, so far as high acid is concerned.

A reference to Tables 2 and 3, which give details of experiments intended to cover this point, shows that the sooner a high-acid cheese is placed in cold storage the better it is for the cheese. This is borne out by the scoring of the cheese in lot 1 . The cheese that was left in the factory curing room for a week before going into storage showed decidedly acid and was badly injured, while that which went directly into storage was not injured in either texture or color. In all the other lots the scores show that the effect of the high acid was minimized by early storage.

The favorable effect that immediate storage has on high-acid cheese was very clearly demonstrated also in Table 1 . Lots 4, 12, 14, 15, $16,19,20,22,26$, and 31 described in this table were evidently made up with too much acid. The portions of these lots that remained in the factory curing rooms for any length of time after making showed defects in texture and color, while those that went directly into storage were not injured in the least. The average score on the high-acid lots of the cheese just referred to that went into storage at once was 78 , while the arerage seore of the lots that went into storage in one week was $7 t$. Similarly the scores of the lots in Table 2 were 72.5 and 67.2 , respectively.

In so-called dead-sour cheese early storage will minimize the damage, but it is not a cure, as is evidenced by lot 5 in Table 3 . However, the buyers ean usually detect these very sour cheeses at an early age, and there is no danger of deception. From these experiments 
it woukd appear that the objection on the part of the buyers to handling a cheese direct from the press is not well founded.

\section{CONCLUSIONS.}

1. In the process of making Chedhar cheese a too high development of whey acid injures the flaror as well as the texture of the eurd.

2. The development of acid in the matted curd overcomes gas and bad taints and does not injure the flavor and texture.

3. Cheese with high arid should be put into cold storage as early as possible to minimize the bad effect of the acid. 





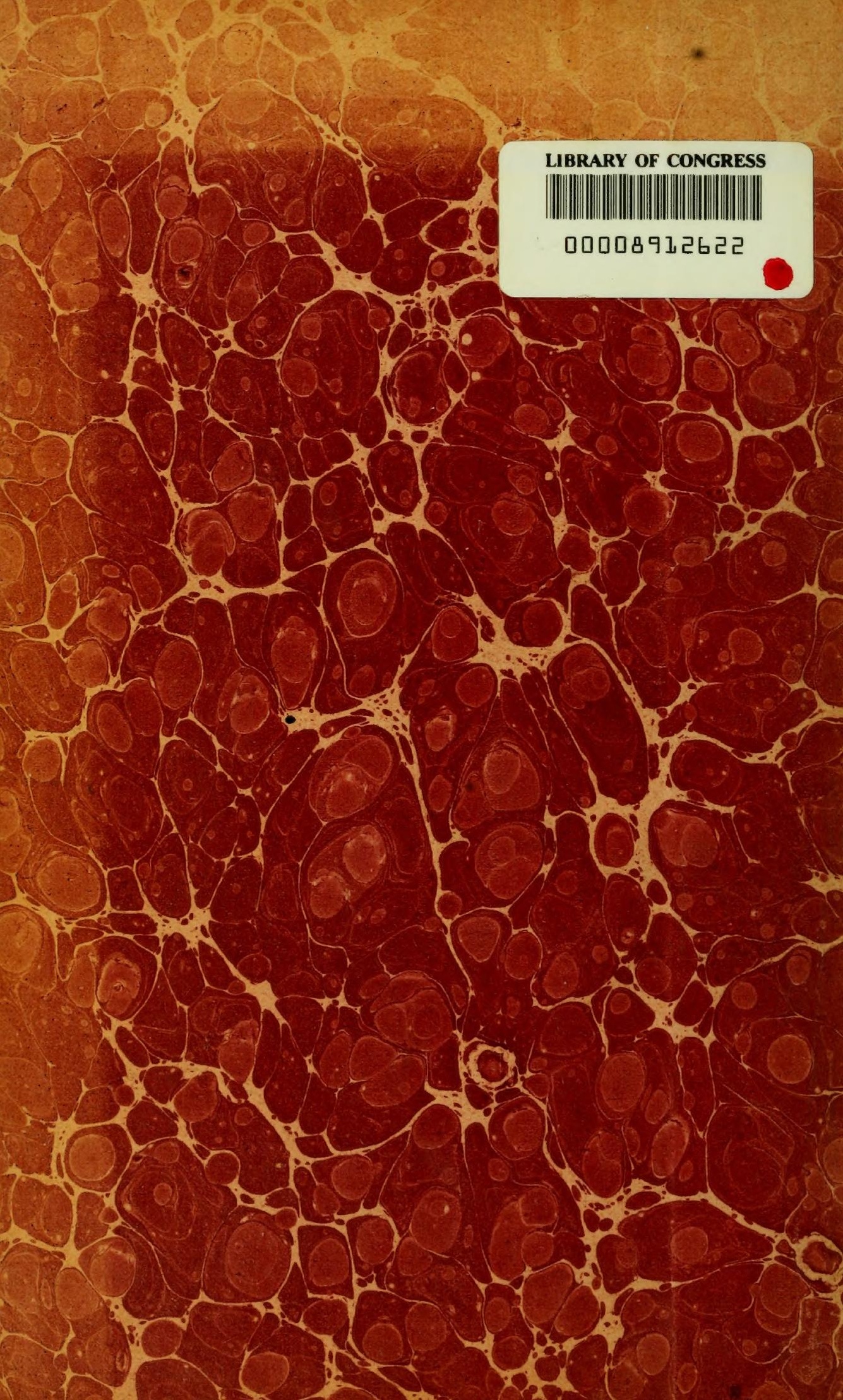

